\title{
Peran Keluarga Dalam Pendidikan Akhlak
}

Oleh: St. Rahmah

\begin{abstract}
Abstrak
Keluarga merupakan unit sosial terkecil dalam masyarakat yang mempunyai peran yang sangat besar untuk mencetak kader-kader yang berkualitas bagi sebuah Negara. Apabila suatu Negara diibaratkan sebuah bangunan, maka keluarga merupakan pondasinya dan apabila Negara diibaratkan sebagai kesatuan tubuh, maka keluarga adalah jantungnya. Kedudukan dan fungsi keluarga dalam kebidupan manusia adalah termasuk hal yang penting karena bersifat dasar yang pada bakikatnya keluarga merupakan wadah pendidiken awal yang membentuk watak dan akblak bagi anak.

Anak adalah amanah Allah yang harus dijaga dan dididik untuk mencapai keutamaan dalam hidup dan mendekatkan diri kepada Allah. Semua bayi yang dilabirkan di dunia ini bagaikan sebuah mutiara yang belum diukur dan belum berbentuk. amanat bernilai tinggi. Karena itu kedua orang tuanyalah yang akan mengukir dan membentuknya menjadi mutiara yang berkualitas tinggi dan berakblak mulia. Maka ketergantungan anak kepada pendidiknya termasuk kepada orang tuanya akan tampak sekali. Kedekatan ayah ibu (orang tua) dengan anak, jelas memberikan pengaruh yang paling besar dalam proses pendidikan (pembentukan) akblak, dibanding pengaruh yang diberikan oleh komponen pendidikan lainnya. Karena ikatan ibu bapak dengan putera puterinya adalah lebih kuat daripada ikatan persaudaraan dan ikatan lainnya.

Pendidikan dalam keluarga merupakan lembaga pendidikan pertama yang pernah ada dalam peradaban manusia sebelum mengenal dengan pendidikan formal. Pendidikan tertua ini pun dikenal sebagai salah satu dari pendidikan informal yang berlangsung secara terus-menerus tanpa terorganisir dengan tujuan dan ciriciri tersendiri. Sebingga dalam hal ini pendidikan informal tidak hanya paling tua, tetapi menurut sejarahnya juga paling banyak kegiatannya, paling luas jangkanannya, tidak membatasi usia (meliputi berbagai usia) dan tidak dibatasi oleh waktu, kapan dan di mana saja.
\end{abstract}

Key word: Keluarga, Pendidikan Akblak

\section{A. Pendahuluan}

Menurut Undang-Undang Nomor 20 Tahun 2003 bahwa keluarga merupakan salah satu penanggung jawab pendidikan, disamping masyarakat dan pemerintah. Keberadaan orang tua sebagai penanggung jawab utama dalam menanamkan nilai-nilai paling dasar sebelum anak masuk dalam komunitas berikutnya, karena keluarga dapat dipandang sebagai lembaga pendidikan yang sangat vital bagi kelangsungan pendidikan generasi muda maupun bagi pembinaan bangsa pada umumnya.

Keluarga merupakan masyarakat terkecil dan menjadi pilar bagi tegaknya masyarakat makro yaitu umat. Sebuah keluarga dapat terbentuk karena adanya ikatan laki-laki dan perempuan melalui sebuah pernikahan yang sah baik menurut hukum negara maupun syari'at Islam.
Allah swt memberikan nikmat kepada mereka yang menjadi perhiasan dan perekat dalam berumah tangga yakni anak. Betapa hambarnya keluarga yang tidak dihiasi dengan kehadiran anak-anak, bahkan tidak jarang sebuah keluarga terpaksa berantakan gara-gara anak yang dinantinantikan tidak kunjung tiba. Namun, adakalanya anak juga menjadi musuh, betapa banyak orang tua yang hidup sengsara karena tingkah polah anak-anak, mereka tidak lagi menjadi kebanggaan, namun justru menjadi sumber bencana dan penderitaan.

Seiring dengan terjadinya perkembangan global disegala aspek kehidupan, selain mengindikasikan kemajuan umat manusia di satu sisi, juga mengindikasikan kemunduran akhlak disisi lain. Hal ini dikarenakan kemajuan kebudayaan melalui pengembangan ilmu pengetahuan dan teknologi (IPTEK) tidak 
diimbangi dengan kemajuan moral akhlak. Ironisnya, semakin tinggi kemajuan teknologi yang dihasilkan semakin membuat manusia kehilangan jati dirinya yang sesungguhnya atau membuatnya menjadi tidak manusiawi.

Pendidikan dalam keluarga merupakan salah satu upaya mencerdaskan kehidupan bangsa melalui pengalaman seumur hidup.

Karena pendidikan dalam keluarga memberikan keyakinan agama, nilai budaya yang mencakup nilai, moral, dan aturan pergaulan serta pandangan, ketrampilan dan sikap hidup yang mendukung kehidupan bermasyarakat, berbangsa dan bernegara kepada anggota keluarga yang bersangkutan.

\section{Fungsi Keluarga}

Keluarga menurut Depkes (1988) dalam Setiawati (2008) adalah unit terkecil dari masyarakat yang terdiri atas kepala keluarga dan beberapa orang yang terkumpul dan tinggal di suatu tempat dibawah suatu atap dalam keadaan saling ketergantungan. Keluarga yang harmonis selalu berupaya untuk menjalankan fungsinya dengan semestinya. Fungsi ini mengacu pada interaksi anggota keluarga terutama pada kualitas hubungan dan interaksi mereka (Wong, 2009). Menurut Friedman (1998) ada 5 fungsi keluarga, yaitu fungsi afektif (affective function), fungsi sosialisasi dan penempatan sosial (socialization and social placement function), fungsi reproduksi (reproductive function), fungsi ekonomi (economic function), fungsi perawatan dan pemeliharaan kesehatan (health care function).

Keluarga merupakan fokus umum dari pola lembaga sosial. Hampir dalam setiap masyarakat keluarga merupakan pusat kehidupan secara individual, dimana di dalamnya terdapat hubungan yang intim dalam derajat yang tinggi. Terlepas dari persoalan hubungan yang inti ini, keluarga mempunyai sejumlah fungsi yang sesuai dengan harapan-harapan masyarakat. Fungsifungsi dari keluarga tersebut meliputi :

a. Fungsi Reproduksi atau Melanjutkan

Keturunan

Keluarga merupakan lembaga yang salah satu fungsinya untuk mempertahankan kelangsungan hidup manusia, melalui fungsi reproduksi. Dalam suatu masyarakat yang beradab, keluarga merupakan satu-satunya wahana untuk maksud ini. Berlangsungnya fungsi ini berkaitan erat dengan aktivitas seksual antara laki-laki (suami) dan wanita (istri). Hanya melalui keluargalah aktivitas seksual manusia yang merupakan kunci terlaksananya fungsi melanjutkan keturunan dapat terpenuhi secara tepat, wajar dan teratur dari segi moral, kultural, sosial, maupun kesehatan dan tentunya sah berdasarkan hukum adat, hukum agama, dan hukum negara.

b. Fungsi Afeksi atau Kasih Sayang

Setiap manusia membutuhkan kasih sayang, karena kebutuhan ini menyangkut perasaan atau emosi seseorang. Keluarga merupakan salah satu pranata yang dapat memenuhi kebutuhan para anggotanya akan kasih sayang. Keluarga yang ideal adalah keluarga yang dipenuhi dengan hubungan kasih sayang di antara anggotanya. Rasa cinta dan kasih sayang sangat berperan penting bagi perkembangan pribadi setiap anggota keluarga, terutama anak-anak.

Anak, terutama pada saat masih kecil, berkomunikasi dengan lingkungan dan orang tuanya dengan keseluruhan kepribadiannya. Pada saat anak masih kecil ini, fungsi afeksi atau kasih sayang memegang peranan sangat penting. Ia dapat merasakan dan menangkap suasana perasaan yang meliputi orang tuanya apda saat anak berkomunikasi dengan mereka. Dengan kata lain, anak peka sekali dengan iklim emosional (perasaan) aau afeksional yang meliputi keluarganya.

Anak membutuhkan kehangatan kasih sayang dari orang tuanya, namun tidak secara berlebihan 
ataupun kekurangan. Oleh karena itu, orang tua terutama ibu, mesti melaksanakan fungsi afeksi ini dengan baik agar jiwa anak tumbuh dengan sehat. Sebuah suasana keluarga yang hangat, romantis, dan penuh kasih sayang akan menumbuhkan kepribadian yang baik bagi anak dan dapat menghindarkan pengaruh psikologis yang tidak baik.

c. Fungsi Ekonomi

Setiap keluarga harus dapat memenuhi kebutuhan ekonomi anggotanya, dapat bertahan hidup. Untuk itu setiap anggota keluarga harus bekerja sama untuk menghasilkan sesuatu. Misalnya: ayah sebagai kepala keluarga berkewajiban bekerja mencari nafkah untuk memenuhi kebutuhan hidup anggota keluargaya. Sedangkan ibu bertugas untuk mengelola keuangan keluarga. Namun saat ini, sudah banyak ibu atau isteri yang turut bekerja untuk membantu keuangan keluarga.

Fungsi ekonomi keluarga sangat penting bagi kehidupan keluarga, karena merupakan pendukung utama bagi kebutuhan dan kelangsungan keluarga. Fungsi ekonomi keluarga meliputi pencarian nafkah, perencanaannya serta penggunaannya. Pelaksanaan fungsi ekonomi keluarga oleh dan untuk semua anggota keluarga mempunyai kemungkinan menambah saling pengertian, solidaritas, dan tanggung jawab bersama dalam keluarga itu. Pemenuhan fungsi keluarga ini mesti dilakukan secara wajar, artinya tidak kekurangan atau berlebihan karena dapat membawa pengaruh negatif bagi anggota keluarga itu sendiri.

d. Fungsi Edukatif atau Pendidikan

Sebagai salah satu pusat pendidikan, keluarga mempunyai tugas yang sangat fundamental dalam upaya mempersiapkan anak bagi peranannya pada masa yang akan datang. Dalam lingkungan keluarga sudah mulai ditanamkan dasar-dasar perilaku, sikap hidup dan kebiasaan lainnya.
Dengan demikian perlu diciptakan lingkungan keluarga yang kondusif bagi terbentuknya kepribadian anak. Di sini lah terlihat begitu banyak fungsi keluarga untuk membentuk perkembangan kepribadian anak baik jasmani maupun rohani.

Fungsi edukatif atau fungsi pendidikan keluarga merupakan salah satu tanggung jawab yang paling penting yang dipikul oleh orang tua. Keluarga merupakan lingkungan pendidikan yang pertama bagi anak. Yang berperan melaksanakan pendidikan tersebut adalah ayah dan ibunya. Kehidupan keluarga sehari-hari pada saat-saat tertentu beralih menjadi situasi pendidikan yang dihayati oleh anak-anaknya.

Dalam lingkungan keluarga anak-anak dididik mulai dari belajar, berjalan, sikapnya, perilaku keagamaannya, dan pengetahuan serta kemampuan lainnya. Memang karena sekarang berbagai kemampuan yang harus dikuasai anak begitu kompleksnya, maka tidak semua hal dapat diajarkan atau dididik dari orang tua, sehingga anak-anak meski dikirim ke sekolah. Namun demikian pendidikan di keluarga tetap merupakan dasar atau landasan utama bagi anak (khususnya dalam pembinaan kepribadian) untuk mengembangkan pendidikan selanjutnya.

Dengan demikian pendidikan dalam keluaga akan membimbing anak dalam kecerdasan intelektual, emosional dan spiritual. Karena dalam keluarga anak dididik untuk berpikir kritis dengan cara selalu berdialog kepada anak untuk memecahkan masalah dan dalam keluarga anak pun dididik untuk dapat menghargai dan menghormati orang lain seperti ketika sedang berbicara anak dilarang untuk memotong pembicaraannya dan ketika libur sekolah anak membantu pekerjaan nya di rumah.

e. Fungsi Sosialisasi

Fungsi sosialisasi mempunyai kaitan yan sangat erat dengan fungsi pendidikan, karena dalam 
fungsi pendidikan terkandung upaya sosisalisasi, yang pertama di lingkungan keluarganya. Orang tua mempersiapkan dia untuk menjadi anggota masyarakat yang baik.

Di lingkungan keluarganya anak dilatih untuk hidup bermasyarakat dibina dan dikenalkan dengan nilai-nilai dan norma-norma yang berlaku di masyarakatnya, sehingga pada masanya anak benar-benar siap terjun di tengah-tengah masyarakat. Dengan melaksanakan fungsi sosialisasi ini dapat dikatakan bahwa keluarga menduduki kedudukan sebagai penghubung anak dengan kehidupan sosial di masyarakat.

f. Fungsi Religius atau Agama

Keluarga mempunyai fungsi religius. Artinya keluarga berkewajiban memperkenalkan dan mengajak anak dan anggota keluarga lainnya kepada kehidupan beragama. Untuk melaksanakannya orang tua sebagai tokoh inti dalam keluarga itu serta anggota lainnya terlebih dahulu haurs menciptakan iklim atau suasana religus dalam keluarga itu.

Agama adalah kebutuhan dasar bagi setiap manusia yang ada sejak dalam kandungan. Keluarga adalah tempat pertama seorang anak mengenal agama. Keluarga juga menanamkan dan menumbuhkan serta mengembangkan nilainilai agama, sehingga anak menjadi manusia yang berakhlak baik dan bertaqwa.

Pembinaan rasa keagamaan anak lebih awal akan lebih baik. Di lingkugan keluargalah pertamatama anak mesti dibiasakan dalam kehidupan beragama tersebut. Anak akan mempunyai keyakinan agama dan landasan hidup yang kuat jika keluarga mampu melaksanakan fungsi religius ini dengan baik.

g. Fungsi Protektif atau Perlindungan

Keluarga mempunyai fungsi sebagai tempat berlindung bagi anggota keluarga. Dalam hal ini dimaksudkan bahwa keluarga harus memberikan rasa aman, tenang dan tenteram bagi anggota keluarganya.
Keluarga dapat menjalankan fungsi protektif atau fungsi memberikan perlindungan bagi seluruh anggota keluarga. Di antara alasan seseorang melangsungkan perkawinan dan membentuk keluarga adalah untuk mendapatkan rasa keterjaminan dan keterlindungan hidupnya, baik secara fisik (jasmani) maupun psikologis (rohani).

Misalnya seorang istri akan merasa hidupnya terjamin dan terlindungi serta tentram di samping suaminya. Dalam keluarga anak-anak pun terasa terlindungi oleh kasih sayang kedua orang tuanya. Pendidikan yang diterima anak pada dasarnya juga bersifat melindungi, yaitu melindungi anak dari perbuatan-perbuatan yang tidak baik dan dari hidup yang tersesat. Sosialisasi yang diterima anak di lingkungan keluarga juga memberikan rasa aman untuk mampu bergaul dalam lingkungan sosial masyarakatnya. Jadi fungsi perlindungan dari keluarga terhadap anak meliputi perlindungan lahir dan batin.

h. Fungsi Rekreasi

Fungsi rekreasi ini ini tidak berarti bahwa keluarga seolah-olah harus berpesta pora atau selalu berekreasi di luar rumah. Rekreasi itu dirasakan orang apabila ia menghayati suatu suasana yang tenang dan damai, jauh dari ketegangan batin, segar dan santai serta kepada yang bersangkutan memberikan perasaan bebas terlepas dari kesibukan sehari-hari.

Fungsi rekreasi sangat penting bagi anggota keluarga, karena dapat menjamin keseimbangan kepribadian anggota-anggota keluarga, mengurangi ketegangan perasaan, meningkatkan saling pengertian, memperkokoh kerukunan dan solidaritas keluarga, meningkatkan rasa kasih sayang dan sebagainya.

i. Fungsi Pengendalian Sosial

Secara umum pengendalian sosial dalam keluarga dilakukan oleh orang tua terhadap anak, tetapi dapat juga terjadi sebaliknya, seorang anak dapat 
melakukan pengendalian sosial terhadap orang tuanya, yang dinilai akan/telah melakukan pelanggaran terhadap norma yang berlaku. Karena pada hakekatnya keluarga merupakan kesatuan sosial yang tidak dapat dipisahkan antara anggota keluarga yang satu dengan yang lain.

Pada dasarnya pengendalian sosial dilakukan untuk mengembalikan suatu kondisi/keadaan di masyarakat ( keluarga ) agar kembali mengikuti kaidah-kaidah yang berlaku.Karena bila tidak dilakukan pengendalian sosial keseimbangan sosial dapat mengalami kegoyahan. Demikian pula di dalam keluarga bila tidak dilakukan upaya pengendalian sosial maka dapat menimbulkan kegoyahan di dalam keluarga, seperti pertengkaran, percekcokan dan bahkan dapat menimbulkan perceraian.

Keluarga dapat berperan sebagai agen pengendali sosial (social control) bagi anggota-anggotanya, keluarga dapat melakukan upaya preventif (pencegahan) terhadap anggotanya agar tidak melakukan perilaku menyimpang dari nilai dan norma yang berlaku di masyarakat. Keluarga juga dapat melakukan upaya kuratif, misalnya dengan mengingatkan, menyadarkan ataupun menghukum anggota keluarganya yang telah melakukan perilaku yang menyimpang atau melanggar nilai dan norma keluarga maupun masyarakat.

\section{Peran Keluarga Dalam Pendidikan Akhlak}

Hidup tidak bisa dilepaskan dari pendidikan, karena manusia diciptakan bukan sekedar untuk hidup, ada tujuan yang lebih mulia dari sekedar hidup yang semestinya diwujudkan dan itu memerlukan ilmu yang diperoleh lewat pendidikan. Ini merupakan salah satu perbedaan antara manusia dengan makhluk lainnya yang membuat lebih unggul dan lebih mulia. Pendidikan dipandang sebagai salah satu aspek yang memiliki peranan pokok dalam membentuk generasi mendatang karena dengan pendidikan akan dapat menghasilkan manusia-manusia yang berkualitas dan bertanggung jawab serta mampu mengantisipasi masa depan.

Menurut undang-undang RI Nomor 20 tahun 2003 pendidikan adalah usaha sadar dan terencana untuk mewujudkan suasana belajar dan proses pembelajaran agar peserta didik secara aktif mengembangkan potensi dirinya untuk memiliki kekuatan spiritual keagamaan, pengendalian diri, kepribadian, kecerdasan, akhlak mulia, serta keterampilan yang diperlukan dirinya masyarakat, bangsa dan Negara. (Undang-undang RI Nomor 20 Tahun 2003; 2003;4) Sedangkan Pendidikan Agama Islam menurut Zakiah Darajat adalah usaha berupa bimbingan dan asuhan terhadap anak didik agar kelak setelah selesai pendidikannya dapat memahami dan mengamalkan ajaran agama Islam serta menjadikannya sebagai pandangan hidup (Zakiah Daradjat; 1996; 86)

Dengan demikian bisa dipahami bahwa Pendidikan Agama Islam adalah sebuah upaya yang dilakukan secara sadar dan terencana dalam menyiapkan peserta didik untuk mengenal, memahami, dan menghayati ajaran agama Islam, sehingga terjadi perubahan dalam kehidupan seseorang dan dapat mengamalkan ajaran Islam serta menjadikan agama Islam sebagai pandangan hidup.

Sedangkan kata akhlak berasal dari bahasa arab berupa jama atau bentuk ganda dari kata khuluq yang secara etimologis berarti budi pekerti, perangai tingkah laku, atau tabiat. Istilah akhlak mengandung arti persesuaian dengan kata khalq yang berarti pencipta, dan makhluq yang berarti yang diciptakan. (Sudirman Tebba; 2005; 65)

Akhlak merupakan kelakuan yang timbul dari hasil perpaduan antara hati nurani, 
pikiran, perasaan, bawaan, dan kebiasaan yang menyatu, membentuk suatu kesatuan tindak akhlak yang dihayati dalam kenyataan hidup keseharian. dari kelakuan itu lahirlah perasaan moral yang terdapat dalam diri manusia sebagai fitrah, sehingga ia mampu membedakan mana yang baik dan mana yang jahat, mana yang bermanfaat dan mana yang tidak berguna (Zakiah Daradjat; 1995;10)

Iman Ghazali mengemukakan bahwa akhlak itu ialah suatu istilah tentang bentuk batin yang tertanam dalam jiwa seseorang yang mendorong ia berbuat (bertingkah laku), bukan karena suatu pemikiran dan bukan pula karena suatu pertimbangan. (Usman Said; 1981; 53)

Membicarakan tentang akhlak tidak akan lepas dengan kepribadian muslim yang pembentukannya Iman, Islam dan Ihsan. Iman seseorang berkaitan dengan akhlaknya. Iman sebagai konsep dasar sedang akhlak adalah aplikasi dari konsep dalam hubungannya dengan sikap dan perilaku sehari-hari.

Pendidikan akhlak adalah dasar dari pembentukan watak dan kepribadian. Watak itu terbentuk melalui proses pembentukan kebiasaan dan pengertian, serta merupakan perpaduan yang meliputi bakat, pendidikan, pengalaman dan alam sekelilingnya, yang menyatakan diri dalam segala rupa tingkah laku. Kepribadian adalah suatu kesatuan fungsianal antara fisik dan psikis atau jiwa dan raga dalam diri individu yang membentuk karakteristik atau ciri khas unik yang terwujud di dalam tingkah laku secara lahiriah maupun sikap batinnya sebagai bentuk penyesuaian dengan lingkungan. Karena itu watak atau kepribadian itu adalah pribadi jiwa yang telah terbentuk yang menyatakan diri dan bercorak sebagai pekerti atau tingkah laku atau organisasai kepribadian melingkupi kerja rohani dan kerja ragawi dalam kesatuan kepribadian.

Pendidikan akhlak merupakan dasar pembentukan watak dan kepribadian, keadaaan individu itu menentukan keadaan wataknya, karena keadaan budi individu itu dalam keadaan baik, maka wataknya serta pekertinya baik, sebaliknya kalau budinya dalam keadaan buruk, maka wataknya akan buruk pula. Jadi pembentukan watak itu merupakan suatu keharusan demi menuju terbentuknya kepribadian yang utama. Dan yang menjadi dasar pembentukan watak adalah mendidik akhlaknya.

Dengan demikian pendidikan akhlak merupakan suatu usaha yang dilakukan dengan sengaja, sistematis untuk mendorong, membantu serta membimbing seseorang dalam mengembangkan segala potensinya serta mengubah diri sendiri kepada kualitas yang lebih tinggi. Dengan kata lain bahwa Pendidikan akhlak adalah usaha secara sadar yang dilakukan manusia dalam rangka mengalihkan, menanamkan pikiran, pengetahuan maupun pengalamannya dalam hal tata nilai terutama nilai-nilai Islami dan cara bersikap atau berperilaku yang baik kepada generasi penerusnya, supaya mereka dapat melakukan fungsi hidupnya dan mencapai kebahagiaan dan kesejahteraan hidup.

Secara paedagogies keluarga diartikan sebagai lembaga pertama dan utama dengan dialami seseorang dimana proses belajar yang terjadi tidak berstruktur dan pelaksanaanya tidak terikat oleh waktu. (Soelaiman Joesoef; 1992; 64)

Lingkungan keluarga, sekolah dan masyarakat merupakan pusat pendidikan, namun diantara ketiganya, lingkungan keluarga menjadi yang paling kuat pengaruhnya terhadap perkembangan anak.( Khatib Ahmad Salthut; 1998; 2) Penguatan mentalitas keberagamaan berawal dari pendidikan yang dilakukan dalam 
lingkungan keluarga. Lingkungan keluarga menjadi institusi pendidikan pertama dalam memberikan pola asuh dan teladan dari orang tua kepada anaknya, sebagai miniatur bagi pembentukan pribadi dan perkembangan anak.

Keluarga sebagai bagian integral dari masyarakat menjadi miniatur yang merepresentasikan kondisi masyarakat. Komunitas keluarga menjadi pondasi penentu bagi keberlangsungan entitas masyarakat. Masyarakat tersusun dari banyak keluarga dan keluarga terdiri dari beberapa individu. Dalam suatu masyarakat biasanya terdapat bermacam-macam lembaga, seperti lembaga pendidikan, lembaga keagamaan, lembaga ekonomi, lembaga perkawinan dan lain-lain. Pada dasarnya, baiknya suatu masyarakat tergantung kepada baiknya keluarga-keluarga dan baiknya suatu keluarga tergantung kepada baiknya individu-individu dalam keluarga, sedang baiknya individu tergantung kepada pembawaan dan lingkungan yang baik. (Muhammad Asyhari; 2006; 246)

Dalam pandangan klasik, pendidikan pada umumnya disebut sebagai pranata yang dapat dijalankan pada tiga fungsi sekaligus; Pertama, menyiapkan generasi muda memegang peranan-peranan tertentu dalam masyarakat di masa depan. Kedua, mentransfer dan memindahkan pengetahuan, sesuai dengan peranan yang diharapkan. Ketiga, mentransfer nilai-nilai dalam rangka memelihara keutuhan dan kesatuan masyarakat sebagai prasyarat bagi kelangsungan hidup (survive) masyarakat dan peradaban.( Hasan Langgulung; 1995; 92)

Para ahli pendidikan pada umumnya mengatakan pendidikan di dalam keluarga ini merupakan pendidikan pertama dan utama. Dikatakan demikian karena di dalam keluarga inilah anak mendapatkan pendidikan pertama kalinya. Di samping itu, pendidikan di dalam keluarga mempunyai pengaruh yang dalam bagi kehidupan anak terutama bagi pertumbuhan dan perkembangan psikis serta nilai-nilai sosial dan religius pada diri anak. Pendidikan dibutuhkan untuk menumbuhkan dasar yang merupakan anugerah dari Allah swt, potensi dasar tidak akan banyak arti dalam kehidupan bila tidak dikembangkan lebih lanjut karena akan tenggelam ke dasar jiwa bahkan akan mati dan tidak ada gunanya.

Pada dasarnya proses pendidikan dalam keluarga berlangsung sepanjang hayat (long life education), selama anggota keluarga masih melakukan interaksi dan komunikasi sosial, maka pendidikan dalam keluarga akan terus bergulir. Pola hubungan antar anggota keluarga, pola asuh orang tua kepada anak, perilaku dan keteladanan orang tua dan sebagainya menjadi aktivitas yang membentuk jati diri anggota keluarga. Interaksi hubungan dalam keluarga merupakan bagian dari pendidikan informal. Pola asah, asih dan asuh dalam keluarga memberikan nuansa bagi transformasi pembelajaran dirumah. Keluarga adalah ruang pertama bagi berlangsungnya edukasi dari orang tua kepada anaknya. Orang tua menjadi sentral dalam memberikan pengasuhan, perhatian, dan pengalaman. Para orang tua disebut pendidik pertama dan keluarga merupakan tempat (ruang) pertama dalam interaksi pendidikan. (Musmuallim; 2012; 27-28)

Pendidikan akhlak dalam keluarga adalah sebuah usaha bimbingan, pengarahan dan latihan dengan membiasakan anak didik agar terbiasa melakukan perbuatan-perbuatan terpuji dan menjauhi perbuatanperbuatan tercela, yang diarahkan kepada pembentukan kepribadian anak, sehingga anak memperoleh sikap dan pengetahuan dari pengalamannya sehari-hari baik secara sadar atau tidak diperoleh dari keluarga. 
Pendidikan dalam keluarga berjalan sepanjang masa, melalui proses interaksi dan sosialisasi di dalam keluarga itu sendiri. Esensi pendidikannya tersirat dalam integritas keluarga, baik di dalam komunikasi antara sesama anggota keluarga, dalam tingkah laku keseharian orang tua dan anggota keluarga lainnya juga dalam hal-hal lainnya yang berjalan dalam keluarga semuanya merupakan sebuah proses pendidikan bagi anakanak. leh karena itu, orang tua harus selalu memberikan contoh tauladan yang baik kepada anak-anak mereka, karena apa pun kebiasaan orang tua di rumah akan selalu dilihat dan dicerna oleh anak-anak.

Disamping itu bahwa proses pendidikan dalam keluarga berjalan secara alamiah dan kultural. Interaksinya tidak memiliki kurikulum secara baku dan sistematis, namun berjalan sesuai tuntunan dan ajaran (syariat) agama Islam, termasuk bagi pemberian pendidikan bagi anggota keluarga, dalam kacamata Islam, pendidikan menempati hal yang wajib (fardu) bagi keberlangsungan tatanan rumah tangga yang harmonis. Sehingga posisi pendidikan dalam keluarga menjadi kebutuhan mendasar (basic needs) sebagai pondasi untuk melanjutkan proses pendidikan selanjutnya diluar rumah. Ketika orang tua mengasuh dan membimbing anak-anaknya dirumah, maka pola yang dilakukan harus memperhatikan ajaran dan tuntunan agama Islam; memberikan kasih sayang, motivasi dan dukungan kepada anaknya, seorang anak berbakti kepada orang tuanya, saling menghormati dan toleran antar anggota keluarga, saling menghargai antara yang muda dan yang tua. Dinamisasi ini akan terwujud ketika seluruh komponen dalam keluarga saling mendukung dan melengkapi.

Pendidikan akhlak perlu diberikan kepada anak sebagai upaya menjaga generasi sejak masa kecil dari berbagai penyelewengan ala jahiliyah, mengembangkan pola hidup, perasaan dan pemikiran mereka sesuai dengan fitrah agar menjadi pondasi yang kuat,pendidikan yang diberikan akan mempengaruhi anak dan akan menjadi bagian dari kepribadiannya. Untuk membangun pondasi yang kuat, dalam diri anak dibutuhkan pendidikan agama sedini. Seorang anak memiliki dua potensi yaitu bisa menjadi lebih baik dan bisa menjadi lebih buruk.

Pendidikan akhlak merupakan bagian yang tidak dapat dipisahkan dari pendidikan agama. Sebab yang baik adalah yang dianggap baik oleh agama dan yang buruk adalah yang dianggap buruk oleh agama. Sehingga nilainilai akhlak, keutamaan-keutamaan akhlak dalam masyarakat Islam adalah akhlak dan keutamaan yang diajarkan oleh agama. Dan seorang Muslim tidak sempurna agamanya sehingga akhlaknya menjadi baik. Para filosof pendidikan Islam hampir semuanya sepakat bahwa pendidikan akhlak adalah jiwanya pendidikan Islam, karena tujuan tertinggi pendidikan Islam adalah mendidik jiwa dan akhlak.

Keluarga memegang peranan penting sekali dalam pendidikan akhlak untuk anakanak sebagai institusi yang pertama sekali berinteraksi dengannya. Oleh karena itu, keluarga harus mengambil porsi yang banyak tentang pendidikan akhlak ini. Mengajar mereka akhlak yang mulia yang diajarkan Islam, seperti kebenaran, kejujuran, keikhlasan, kesabaran, kasih sayang, cinta kebaikan, pemurah, berani dan lain-lainnya. Orang tua juga harus mengajarkan nilai dan faedah berpegang teguh pada akhlak di dalam hidup, dan membiasakan mereka berpegang kepada akhlak sejak kecil.

Dalam keluarga sangat efektif untuk menjalankan pendidikan akhlak karena keluarga adalah "umat kecil" yang memiliki pimpinan 
dan anggota, mempunyai pembagian tugas dan kerja, serta hak dan kewajiban bagi masingmasing anggotanya. Hak dan kewajiban serta lainnya itu lah yang menjadi perekat bagi bangunan keluarga. Allah SWT menetapkan hal tersebut untuk menciptakan keharmonisan dalam hidup berumah tangga yang pada akhirnya menciptakan suasana aman, bahagia dan sejahtera bagi seluruh masyarakat bangsa. Karena dengan melaksanakan pendidikan akhlak dalam keluarga akan mampu menciptakan kader-kader yang berkualitas yang mempunyai budi pekerti luhur, mampu bertanggung jawab dan mempunyai dedikasi yang tinggi, sehingga akan berpengaruh bagi kehidupan sebuah lembaga seperti Negara, disamping itu juga keluarga adalah jiwa masyarakat dan tulang punggungnya. Kesejahteraan lahir dan batin yang dinikmati oleh suatu bangsa, atau sebaliknya, kebodohan dan keterbelakangannya adalah cerminan dari keadaan keluarga keluarga yang hidup pada masyarakat bangsa tersebut.

Pendidikan akhlak harus dilakukan sebelum kerangka watak dan kepribadian seorang anak yang masih suci diwarnai oleh pengaruh lingkungan yang belum tentu paralel dengan tuntunan agama.

Metode penanaman akhlak kepada anak dalam keluarga dapat menggunakan cara-cara sebagai berikut:

a. Metode Keteladanan

Pendidikan dengan keteladanan berarti pendidikan dengan memberi contoh, baik berupa tingkah laku, sifat, cara berfikir dan sebagainya.( Hery Noer Aly; 1999; 178) Keteladanan merupakan metode yang paling baik dalam rangka bimbingan orang tua kepada anaknya, karena setiap anak yang akan menjalani proses kehidupannya, mereka memerlukan keteladanan yang baik dan saleh yang dapat diperoleh dari orang tuanya. (Ali Badawi; 2002; 13), Karena apabila seorang anak dibesarkan dengan bimbingan akhlak yang baik dari orang tua serta lingkungan muslim yang baik, maka ia akan mendapatkan banyak contoh atau keteladanan yang baik untuk perkembangan jiwanya. (Norma Tarazi; 2001; 165).

Dengan demikian keteladanan yang diberikan orang tua pada anak-anaknya akan sangat menentukan keberhasilan orang tua dalam membimbing anak-anaknya. Dan metode inilah yang paling efektif untuk membimbing anaknya. Orang tua tidak hanya memberikan bimbingan secara lisan malainkan juga langsung memberikan contoh kepada anak-anaknya.

b. Metode Pembiasaan

Pembiasaan merupakan salah satu metode dalam mendidik dan membimbing anak, yaitu dengan cara membiasakan anak untuk melakukan perbuatan yang diajarkan dalam agama. Misalnya, membaca basmalah ketika akan melakukan perbuatan yang baik dan mengucapkan hamdalah ketika selesai melakukan suatu perbuatan yang baik supaya mendapatkan keridlaan dari Allah. Karena dengan membiasakan anak-anak untuk berbuat baik dalam kehidupan sehari-hari, maka akan berakibat baik pula pada perilaku anak kelak jika sudah dewasa.

c. Metode Hukuman

Apabila keteladanan dan nasehat tidak mampu, maka waktu itu harus di adakan tindakan tegas yang dapat meletakkan persoalan di tempat yang benar, tindakan tegas itu adalah hukuman. Hukuman merupakan metode terburuk, tetapi dalam kondisi tertentu harus digunakan, karena metode hukuman adalah cara yang paling akhir dilakukan, Oleh karena itu, ada beberapa hal yang hendaknya diperhatikan pendidik dalam menggunakan metode hukuman antara lain: 
1) Hukuman adalah metode kuratif, artinya tujuan hukuman ialah untuk memperbaiki peserta didik yang melakukan kesalahan dan memelihara peserta didik yang lainnya, bukan untuk balas dendam.

2) Hukuman baru digunakan apabila metode lain tidak berhasil guna dalam memperbaiki peserta didik.

3) Sebelum dijatuhi hukuman, peserta didik hendaknya lebih dahulu di beri kesempatan untuk bertaubat dan memperbaiki diri.

4) Hukuman yang dijatuhkan pada peserta didik hendaknya dapat dimengerti olehnya, sehingga ia sadar akan kesalahannya dan tidak mengulanginya.

5) Hukuman psikis lebih baik dari pada hukuman fisik.

6) Hukuman hendaknya disesuaikan dengan latar belakang kondisi peserta didik.

7) Dalam menjatuhkan hukuman, hendaknya diperhatikan prinsip logis, yaitu hukuman disesuaikan dengan jenis kesalahan.

8) Pendidik hendaknya tidak mengeluarkan ancaman hukuman yang tidak mungkin dilakukannya. (Hery Noer Aly; 1999; 200-202)

Dengan demikian 0rang tua sebagai pendidik utama dalam keluarga berkewajiban memperhatikan dengan seksama perkembangan pribadi anak-anaknya termasuk perkembangan moral anak dengan menggunakan cara-cara pendidikan yang baik sehingga menjadi manusia berkepribadian baik dan bermoral baik. Dalam keluarga orang tua bertugas sebagai pemimpin keluarga yang harus memelihara dan melindungi keselamatan hidup dan kehidupan keluarga baik moral maupun materiil.

\section{Penutup}

Keluarga merupakan masyarakat kecil dan menjadi pilar bagi tegaknya masyarakat makro yaitu umat. Sebuah keluarga dapat terbentuk karena adanya ikatan laki-laki dan perempuan melalui sebuah pernikahan yang sah baik menurut hukum negara maupun syari'at Islam.

Keluarga dalam Islam memegang peranan penting dalam membentuk pribadi anak, karena keluarga merupakan institusi pertama yang yang secara langsung berinteraksi dengan anak, sehingga apa pun yang terjadi dalam keluarga akan berdampak terhadap anak.

Pendidikan di dalam keluarga ini merupakan pendidikan pertama dan utama, karena di dalam keluarga inilah anak mendapatkan pendidikan pertama kalinya. Di samping itu, pendidikan di dalam keluarga mempunyai pengaruh yang besar bagi kehidupan anak terutama bagi pertumbuhan dan perkembangan psikis serta nilai-nilai sosial dan religius pada diri anak

Orang tua mempunyai kewajiban untuk menanamkan akhlakul karimah pada anakanaknya yang dapat membahagiakan di alam kehidupan dunia dan akhirat.

\section{Daftar Pustaka}

Ali Badawi, Imbalan dan Hukuman Pengarubnya bagi Pendidikan Anak, Jakarta: Gema Insani Press, 2002

Hasan Langgulung, Beberapa Pemikiran Tentang Pendidikan Islam, Bandung: Al-Maarif, 1995.

Hery Noer Aly, Ilmu Pendidikan Islam, Jakarta: Logos, 1999.

Khatib Ahmad Salthut, Menumbubkan Sikap Sosial, Moral dan Spiritual Anak dalam Keluarga Muslim, Yogyakarta: Mitra Pustaka, 1998.

Muhammad Asyhari, Tafsir Cinta Tebarkan Kebajikan dengan spirit al-Qur'an, Jakarta, Hikmah, 2006. 
Musmuallim, Eksistensi Pendidikan Luar Sekolah, Purwokerto: Majalah Pendidikan Sang Guru, Edisi 024/Th. IV/Mei-Juni 2012.

Norma Tarazi, Wabai Ibu Kenali Anakmu, Yogyakarta: Mitra Pustaka, 2001.

Ridwan Abdullah Sani, Muhammad Kadri, Pendidik.An Karakter "Mengembangkan Karakter Anak Yang Isla", Jakarta, Bumi Aksara, 2016.

Setiawati, Penuntun Praktis Asuban Keperawatan Keluarga, Jakarta: Trans Info Media, 2008.

Soelaiman Joesoef, Konsep Dasar Pendidikan Luar Sekolah, Jakarta: Bumi Aksara, 1992.

Sudirman Tebba, Seri Manusia Malaikat, Yogyakarta, Scripta Perenia, Cet. I, ,2005,

Undang-undang RI Nomor 20 Tahun 2003, Sistem Pendidikan Nasional, Jakarta: Eka Jaya, Cet.1, 2003.

Usman Said, Metodik Khusus Pengajaran Agama Islam, Jakarta: Proyek Pembinaan Prasarana dan Sarana Perguruan Tinggi Agama/LAIN, 1981.

Wong, Buku Ajar Keperawatan Pediatrik, Ed. 6 Vol. 1. Jakarta, EGC, 2009.

Zakiah Daradjat, dkk. Ilmu Pendidikan Islam, Jakarta, Bumi Aksara, Cet. III, 1996.

Zakiah Daradjat, Pendidikan Agama Islam Dalam Keluarga dan Sekolah, Jakarta, Ruhama, 1995. 